\title{
ARTICLE
}

Kefir 배양용 기능성 복합 Starter 개발

이봄이 ${ }^{1} \cdot$ 이해창 $\cdot$ 문용일 $\cdot$ 오세종 ${ }^{3}$

${ }^{1}\left(\right.$ 주)삼익유가공, ${ }^{2}$ 우석대학교 동물자원식품학과, ${ }^{3}$ 전남대학교 동물자원학부

\section{Development of a Functional Mixed-Starter Culture for Kefir Fermentation}

\author{
Bomee Lee ${ }^{1}$, Hae-Chang $\mathrm{Yi}^{1}$, Yong-II Moon ${ }^{2}$, and Sejong $\mathrm{Oh}^{3}$ \\ ${ }^{1}$ Samik Dairy \& Food Co. Ltd., 453 Yeoksam-ro, Seoul, Korea \\ ${ }^{2}$ Dept. of Animal Source Food, Wooseok University, Wanju, Korea \\ ${ }^{3}$ Division of Animal Science, Chonnam National University, Gwangju, Korea
}

Received: September 19, 2018

Revised: September 22, 2018

Accepted: September 26, 2018

${ }^{*}$ Corresponding author :

Sejong Oh

Division of Animal Science, Chonnam

National University, Gwangju, Korea

Tel : +82-62-530-2116

Fax : +82-62-530-2129

E-mail：soh@chonnam.ac.kr

Copyright $\odot 2018$ Korean Society of Milk Science and Biotechnology.

This is an Open Access article distributed under the terms of the Creative Commons Attribution Non-Commercial License (http:/l creativecommons.org/ licenses/by-nc/3.0) which permits unrestricted non-commercial use, distribution, and reproduction in any medium, provided the original work is properly cited.

\section{ORCID}

Bomee Lee

0000-0003-1954-5046

Hae-Chang $\mathrm{Yi}$

0000-0001-7042-2629

Yong-II Moon

0000-0001-5903-2160

Sejong Oh

0000-0002-5870-3038

\begin{abstract}
Kefir, which originates in the Caucasian mountains, is a cultured milk beverage produced by a combination of acidic and alcoholic fermentation. Kefir products are commonly used as food vehicles to deliver health-promoting materials including kefran and lactic acid bacteria to consumers. The aim of this study was to develop a freeze-dried starter culture without yeast and assess the suitability of kefir-like dairy products for the growth of lactic acid bacteria and the acidification of milk.

Pasteurized whole milk (SNF 8.5\%) stored at $25^{\circ} \mathrm{C}$ was aseptically inoculated with starter cultures $(0.002 \% \mathrm{w} / \mathrm{v})$; it was kept at $25^{\circ} \mathrm{C}$ until the $\mathrm{pH}$ attained a value of 4.6. Ten grams of the kefir-like product sample was diluted with $90 \mathrm{~mL}$ of $0.15 \%$ peptone water diluent in a milk dilution bottle, followed by uniform mixing for $1 \mathrm{~min}$. Viable cells of Lactobacillus species were enumerated on modified-MRS agar ( $\mathrm{pH} 5.2$ ), with incubation at $37^{\circ} \mathrm{C}$ for 48 h. Viable cells of Lactococcus species were enumerated on M17-lactose agar, with incubation at $32^{\circ} \mathrm{C}$ for $48 \mathrm{~h}$.

The $\mathrm{pH}$ attained a value of 4.6 after fermentation for $9 \mathrm{~h} 30 \mathrm{~min}$ (Starter 1), 9 h $45 \mathrm{~min}$ (Starter 2), and $12 \mathrm{~h}$ (Starter 3). The viable cell count of Lactobacillus sp. and Lactococcus sp. was initially $10^{5} \sim 10^{6} \mathrm{CFU} / \mathrm{g}$; it increased significantly to $10^{9} \mathrm{CFU} / \mathrm{g}$ after $12 \mathrm{~h}$ of incubation. During the storage of the kefir-like products at $4^{\circ} \mathrm{C}$ for 14 days, the total viable cell numbers were unchanged, but the $\mathrm{pH}$ decreased slightly. The consistency of the kefir products increased gradually during the storage. The organoleptic properties of the kefir products fermented using the new starter culture are more desirable than those of commercial kefir. These results suggest that the newly developed starter culture without yeast could be suitable for kefir fermentation.
\end{abstract}

\section{Keywords}

kefir, starter culture, probiotics, fermentation

\section{서 론}

요구르트와 Kefir는 코카서스 산맥의 Elbrus 산에서 시작되었는데, 남쪽 지역은 요구르트, 북쪽지역 은 Kefir의 탄생지로 알려져 있다(Fig. 1). 여러 종류의 미생물이 적당한 온도의 우유에 옮겨졌고, 인간은 이것을 발견했던 것으로 Elbrus 산의 남쪽 경사면에서는 $40 \sim 45^{\circ} \mathrm{C}$ 의 고온을 선호하는 미생 물이 터키 유목민의 우유통에 우연히 전달되어 우유발효가 되었고, 터키인들은 이를 "Yogurut"라고 불렀다. Yogurut는 11세기에 들어와서 현재의 이름인 요구르트(yoghurt)로 바뀌었다(Bylund, 2003). Kefir는 $25 \sim 28^{\circ}$ C에서 잘 자라는 미생물에 의해 Elbrus 산 북쪽 경사면에서 만들어졌는데, 


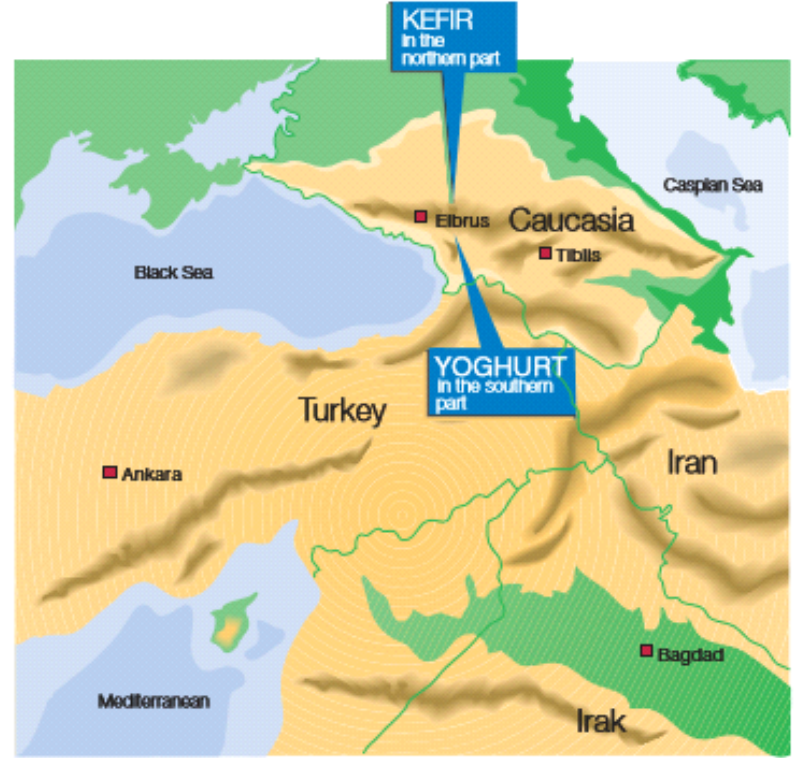

(A)

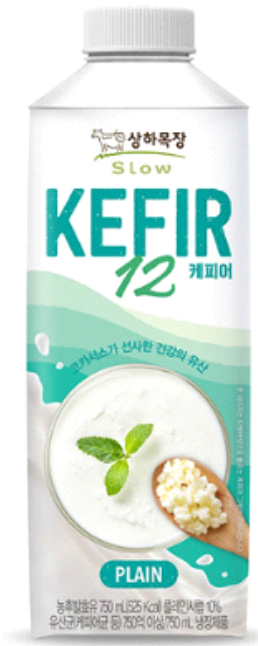

(B)

Fig. 1. The region where Kefir and Yogurt was first made (Bylund, 2003); A, and a Kefir product in Korea; $\mathrm{B}$.

Kefir라는 이름은 터키 언어에서 파생된 것이다. 이름의 첫 번째 음절인 kef는 터키어로 즐겁다는 것을 의미하는데, Kefir는 yoghurt와 다른 유형의 독특한 미생물을 함유하고 있다. 요구르트와 다르 게 Lactococcus 속 유산균과 $\mathrm{CO}_{2}$ 를 생산하는 헤테로발효 유산균 및 효모가 바로 Kefir와 요구르트 와 다른 점이다. 특히, 효모는 알코올을 생성할 수 있기 때문에 Kefir에 존재하는 최대 알코올 함량은 약 $0.8 \%$ 정도로 알려져 있다.

Kefir grain은 점성이 있는 노란색 혹은 유백색의 비정형 형태이다(Guzel-Seydim 등, 2000). 발효 유 제조에 사용되는 종균(단독 혹은 혼합 유산균)을 통상적으로 스타터로 부르지만, Kefir의 경우에는 Kefir grains으로 부르고 있다. Kefir grain은 효모, lactic acid bacteria, acetic acid bacteria 및 mycelial fungi 등으로 구성되어 있다. 우리나라의 김치가 지역별 사용재료별 다양한 미생물 분 포를 나타나는 것과 같이 Kefir도 지역별, 국가별 각기 다양한 미생물 분포를 보인다. Kefir grain에 서 가장 많은 비율을 차지하는 미생물은 Lactobacillus 속 유산균으로 전체 미생물의 65 80\% 정도 를 보인다(Wouters 등, 2002). 나머지 미생물 분포는 lactococci 와 yeasts 등이 차지하고 있다. Kefir에서 분리되는 유산균으로는 Lactobacillus acidophilus, Lactobacillus brevis, Lactobacillus casei, Lactobacillus fermentum, Lactobacillus helveticus, Lactobacillus kefiri, Lactobacillus parakefiri, Lactococcus lactis 및 Leuconostoc mesenteroides 등을 들 수 있다 (Kandler와 Kunath, 1983; Fujisawa 등, 1988; Pintado 등, 1996; Cogan 등, 1997; Takizawa 등, 1998; Micheli 등, 1999; Assadi 등, 2000; Witthuhn 등, 2004).

Kefir에서 분리되는 효모로는 Kluyveromyces marxianus, Torula kefir, Saccharomyces exiguus 및 Candida lambica가 대표적이다(Kwak 등, 1996; Pintado 등, 1996; Garrote 등, 1997; Wyder와 Puhan, 1997; Wyder 등, 1999; Assadi 등, 2000; Witthuhn 등, 2004; ). 또한, 초산을 생산하는 Acetobacter aceti와 A. rasens, 곰팡이 종류인 Geotrichum candidum 등도 분리되었음이 보고되었다(Pintado 등, 1996).

전통방법으로 생산하는 Kefir는 종균의 안정적 확보 및 각 미생물의 함유량을 제어할 수가 없어 Kefir starter에 함유되는 미생물 종류에 따라 제품의 안정성(stability) 및 안전성(safety)에 
많은 영향을 미친다.

국내에서는 티벳 버섯이라는 이름으로 잘못 알려져 있는데, Kefir의 역사적 고찰이나, 다른 문헌에 근거해서도 티벳 버섯이라는 명칭은 그 유래를 찾을 수가 없다. 아마도 일본이나 국내의 광신적인 Kefir 신봉자들이 만든 것으로 추정되는데, 이는 김치를 김치로 부르지 않고 엉뚱한 다른 이름을 지어서 부르는 것과 같은 것으로 참으로 우스꽝스러운 일이 아닐 수 없다.

Kefir의 세계 최대의 소비국으로 러시아는 전체 발효유 중 약 $70 \%$ 를 차지하고 있는데, 요구르트와는 달리 독특한 맛과 건강 효능 때문에 많이 음용하고 있다. 일본에서는 Kefir의 우수한 효능 때문에 최근 학계나 생산업계의 관심이 증대되고 있다. 최근 Kefir가 미국 타임지가 선정한 '행복감을 주는 식품' 중 하나로 국내에 그 소식이 소개되면서 관심이 높아졌는데, 국내에서는 2017년 10월에 매일 유업에서 발효유로 12 종의 유산균이 함유되어 12시간 배양하여 제조한 Kefir12 라는 제품을 처음으 로 출시하였다(Fig. 2). 일본의 메이지 유업에서 Kefir Yogurt Drink, Minami Nihon에서 Kefir Yogurt, Kansai Runa에서 Kefir, Ohayo에서 Kefier 등이 발매되었고, 그 외에 Kefir 발효물을 첨가한 Kefir 응용제품이 5 6종 출시되었다.

본 연구는 효모를 함유하지 않은 유산구균과 유산간균으로 구성된 스타터를 개발하기 위하여 Kefir 배양시 생균수 변화 및 Kefir 제조 특성에 대한 기초자료를 얻고자 수행하였다.

\section{재료 및 방법}

\section{Kefir의 제조}

살균된 우유에 제조된 스타터를 $0.02 \%(\mathrm{w} / \mathrm{w})$ 를 접종하여 $25^{\circ} \mathrm{C}$ 에서 정치 배양하면서 Kefir를 제조하 였다. 판매 중인 상업용 스타터는 $2 \%$ 를 접종하였다. 배양액의 $\mathrm{pH}$ 가 4.5 에 이르면 배양을 종료시켰으 며, 바로 냉각하여 Kefir를 완성하였다.

\section{2. 유산균수 평가}

유산균수의 측정은 $\mathrm{pH}$ 를 5.2로 조정한 MRS-lactose 배지에 Kefir 시료를 도말하여 $37^{\circ} \mathrm{C}$ 에서 48시 간 동안 혐기성 배양기에서 배양한 후 집락을 계수하였다.

Lactococcus 균수의 측정은 M17-lactose 배지에서 $30^{\circ} \mathrm{C}$ 에서 24 시간 혐기적 조건에서 배양한 후 집락을 평가하였다.

\section{Kefir 스타터의 저장중 생균수 변화}

제조된 스타터는 산소투과가 거의 없는 알루미늄코팅 비닐에 진공포장하여 저장시료로 사용하였다.
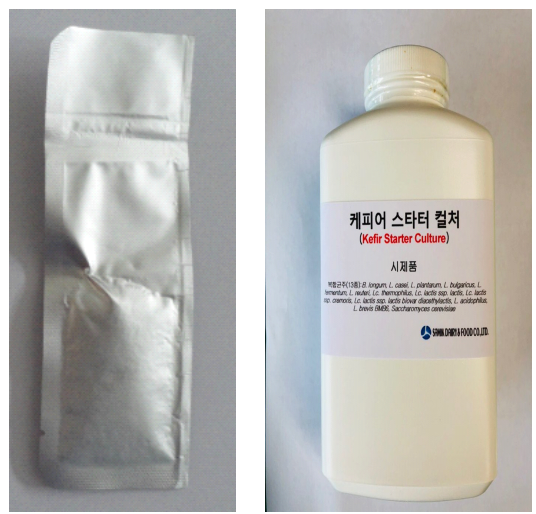

Fig. 2. Developed-starter culture in this study. 
제조된 스타터는 $-20^{\circ} \mathrm{C}$ 와 $5^{\circ} \mathrm{C}$ 에서 각각 저장한 다음 12 주 동안 저장하면서 생균수를 평가하였다.

\section{4. $\mathrm{pH}$ 및 적정 산도의 측정}

$\mathrm{pH}$ 는 $\mathrm{pH}$ meter(FEP20; Mettler Toledo; Greifensee, Switzerland)를 사용하여 측정하였으며, 적정산도는 시료 $9 \mathrm{~g}$ 을 적정하는데 소요되는 $0.1 \mathrm{~N} \mathrm{NaOH}$ 의 mL 수로 환산하였다.

\section{결과 및 고찰}

\section{Kefir Starter의 저장 안정성 평가}

제조된 스타터(Fig. 2)를 $-20^{\circ}$ C와 $5^{\circ} \mathrm{C}$ 에서 각각 저장하면서 생균수를 평가한 결과는 Fig. 3에서 보는 바와 같다. 냉동보관의 경우, 스타터 초기 균수의 $10^{10} \mathrm{CFU} / \mathrm{g}$ 를 4 개월간 유지하는 것으로 나타 났으며, 냉장 보관의 경우 $2 \sim 6 \times 10^{10} \mathrm{CFU} / \mathrm{g}$ 의 생균수를 유지하는 것으로 나타났다.

Yeast가 첨가되지 않아 original Kefir 논란이 있지만, yeast는 다른 우유제품과 발효유 제품에서 제품 변질(탄산가스에 의한 용기 팽창)의 주된 원인 미생물로 공정상 반드시 제어되어야 한다. 따라서 본 개발 starter에는 타 유제품에 영향을 줄 수 있는 yeast를 첨가하지 않고, 유산구균과 유산간균 만으로 조성을 완성하였다. Table 1은 본 연구에서 개발한 Kefir starter의 specification을 나타낸 것이다. 개발 starter는 유산균 12 species를 함유하며, L. acidophilus의 경우 2종이 함유되어 있 어 실제적으로 총 13 종류로 구성되었다. 본 연구에서는 동일 유산균주들을 사용하여 각 유산균 혼합 비율을 다르게 하여 Starter 1, 2, 및 3을 완성하였다.

\section{Kefir 제품의 배양중 특성}

제조 후 총 생균수는 스타터 의 경우 $4.5 \times 10^{10} \mathrm{CFU} / \mathrm{g}$ 이었으며, 장기간동안 다소간의 증감이 있었으 나, 이것은 측정오차로 파악되었다. 냉동저장 12 주 후 $4.3 \times 10^{10} \mathrm{CFU} / \mathrm{g}$, 냉장 저장 12 주 후에는 $2.1 \times 10^{10} \mathrm{CFU} / \mathrm{g}$ 로 나타났다.

본 연구에서 완성한 스타터 2 의 경우에는 제조 직후 생균수는 $3.97 \times 10^{10} \mathrm{CFU} / \mathrm{g}$ 이었으며, 냉동저장 12 주 후 $3.89 \times 10^{10} \mathrm{CFU} / \mathrm{g}$, 냉장 저장 12 주 후에는 $2.52 \times 10^{10} \mathrm{CFU} / \mathrm{g}$ 로 초기균수를 유지하는 것으로 나타났다.

\section{Kefir의 제조}

살균된 우유에 제조된 스타터를 $0.02 \%(\mathrm{w} / \mathrm{w})$ 를 접종하여 $25^{\circ} \mathrm{C}$ 에서 정치 배양한 결과, $\mathrm{pH}$ 에 4.5 에
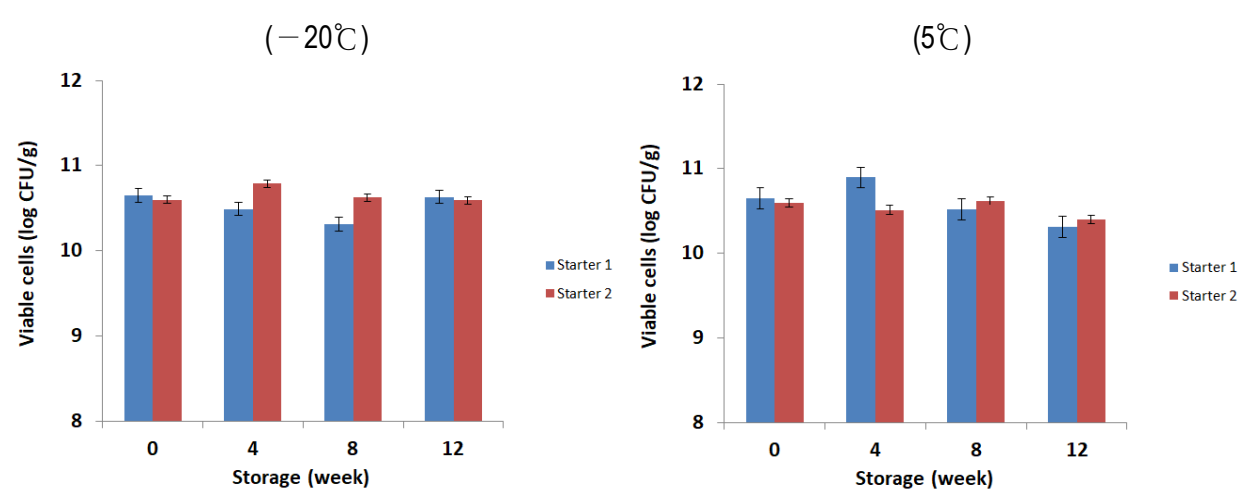

Fig. 3. Changes of viable cells of Kefir starter during storage. 
Table 1. The sheet of Kefir starter specification

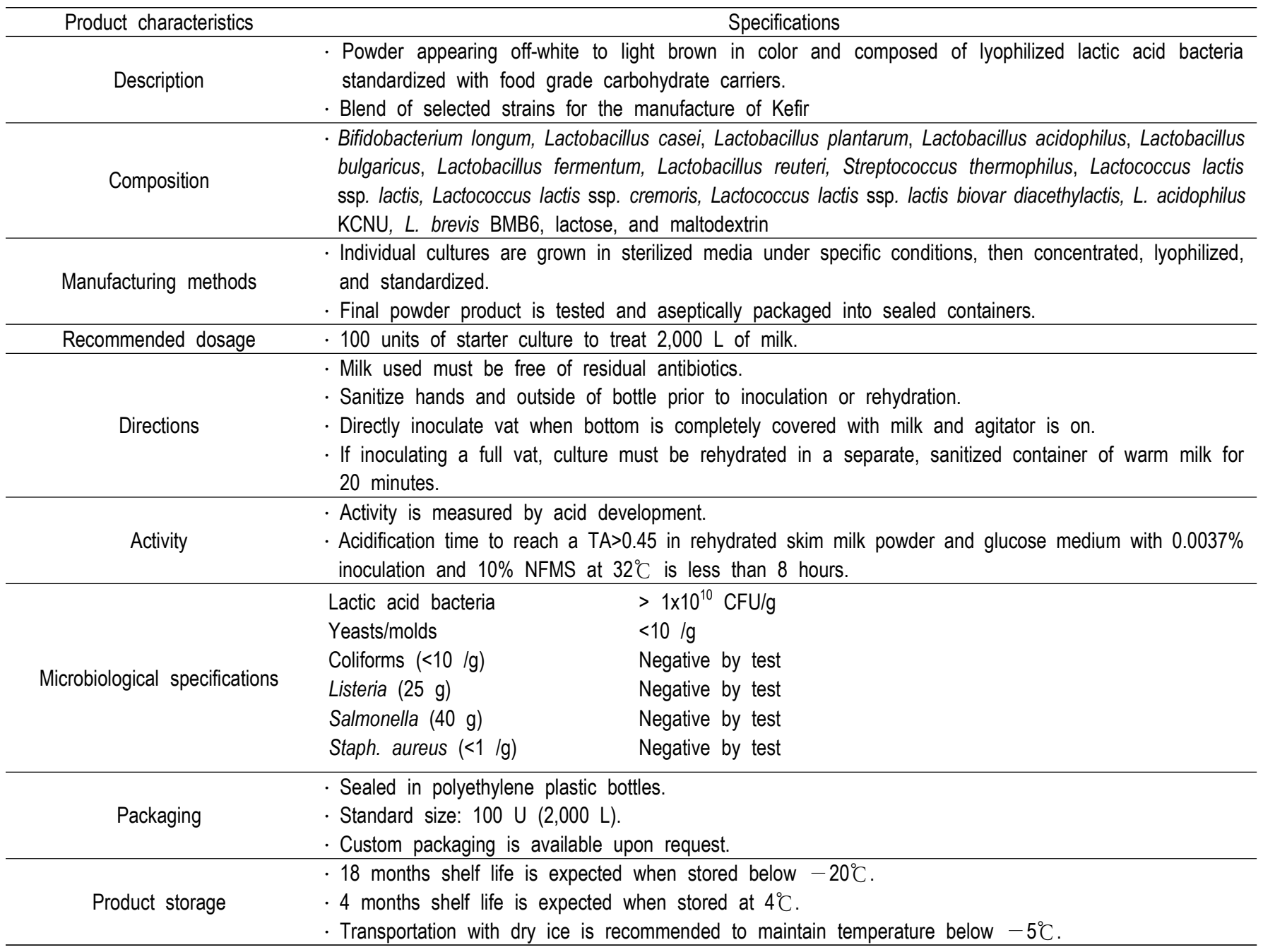

도달하는 시간은 스타터 1 의 경우 9시간 30 분, 스타터 2 의 경우 9시간 45 분이 걸렸다. 그러나 판매 중인 상업용 스타터는 12 시간이 소요되었다. Kefir를 배양하면서 생균수를 평가한 결과는 Fig. 4 에 보는 바와 같다. $0.02 \%(\mathrm{w} / \mathrm{w})$ 접종시 초기 생균수는 약 $10^{5} \sim 10^{6} \mathrm{CFU} / \mathrm{mL}$ 정도로 나타났다. Lactobacillus의 총균수는 배양 12 시간이 지나야 약 $10^{8} \sim 10^{9} \mathrm{CFU} / \mathrm{mL}$ 에 이르렀으며, Lactococcus 속 유산균의 생균수는 배양 8시간에 약 $10^{8} \sim 10^{9} \mathrm{CFU} / \mathrm{mL}$ 에 도달하는 것으로 확인되었다. 따라서 Kefir 제품의 생산을 위한 적정 배양시간은 8시간 정도로 생각되었다.

\section{Kefir 배양 중 $\mathrm{pH}$ 의 변화}

발효유의 경우, 기호성이 가장 좋은 $\mathrm{pH}$ 는 당류를 첨가하지 않은 경우 $\mathrm{pH} 4.5 \sim 4.8$ 정도이고, 당류를 첨가하는 경우 $\mathrm{pH}$ 4.2 4.3 정도이다. Fig. 5에서 나타난 바와 같이, 배양 4시간에 $\mathrm{pH}$ 5.1 5 정도 로 저하되었으며, 배양 12 시간에는 $\mathrm{pH} 4.3 \sim 4.2$ 정도까지 저하되었다. 스타터 1과 스타터 2는 Kefir 배양 8시간에 $\mathrm{pH} 4.7$ 정도로 나타나, 적정배양시간은 8 9시간 정도로 생각되었다.

그러나 산업적 생산시에는 배양탱크에서 이송하는 시간이 있으므로 배양 8 시간 이내에 배양을 종료 하는 것이 적절한 것으로 생각된다.

요구르트의 경우, Streptococcus thermophilus와 Lactobacillus delbrueckii ssp. bulgaricus의 
MRS-pH 5.2

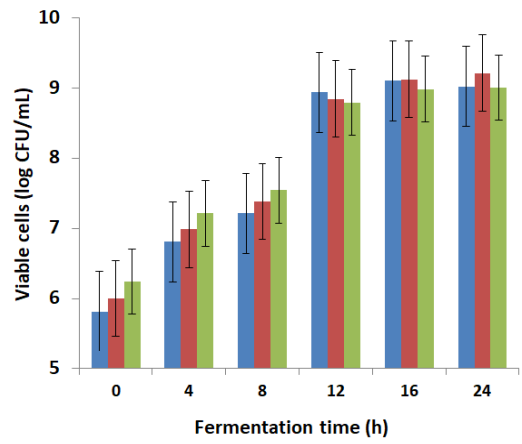

M17-lactose

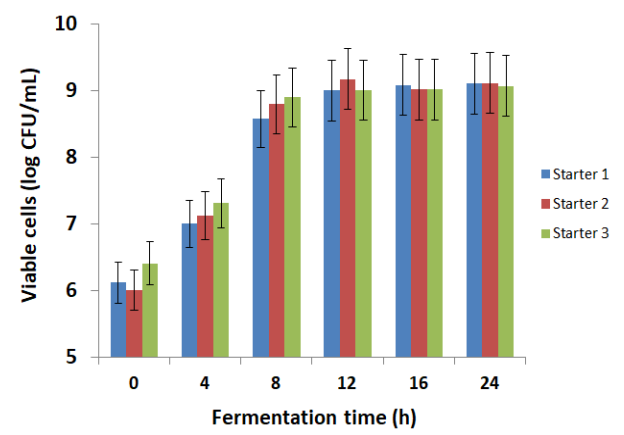

Fig. 4. Changes of viable cells during Kefir fermentation.

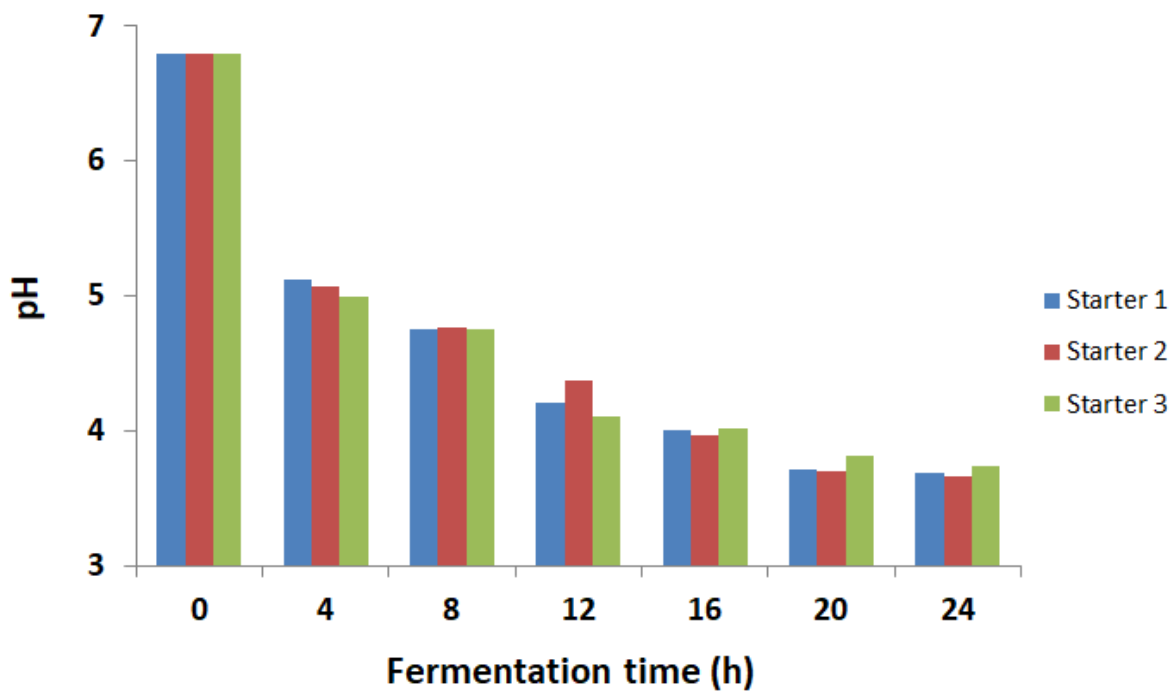

Fig. 5. pH decline curve during Kefir fermentation.

혼합된 starter를 사용하는데, 배양 초기의 acid production은 주로 $S$. thermophilus에 의해 이루 어진다. S. thermophilus는 우유에 있는 lactose를 permease에 의해 세포 안으로 가지고 들어와서 바로 에너지 생산에 이용하기 때문이다.

Starter를 구성하고 있는 유산균의 종류에 따라 우유 배양 시간이 다소 다르며, 풍미 물질 생성 또한 다소 차이가 있는데, 이는 lactic acid 이외에 다른 metabololites를 만들기 때문이다. 다른 우유배 양과 마찬가지로 Kefir 배양 중에 유산균들은 우유내 유당은 젖산으로 빠르게 전환시킨다. 또한 Kefir starter에 함유된 풍미를 생산하는 유산균들에 의해 diacetyl, acetic acid, propionic acid, ketones, aldehydes, fatty acids 등의 물질들이 만들어진다. Starter내의 다양한 유산균들은 서로 간 symbiotic relationship으로 우유의 $\mathrm{pH}$ 가 5 이하로 저하되면 acetaldehyde를 생산하기 시작 하여 $\mathrm{pH}$ 4.2 4.0에 이르러서 최대 함량을 보인다(Tamime과 Robinson, 1999).

발효유제품의 배양시 생산되는 향미성분은 비휘발성 물질, 휘발성 물질 및 carbonyl 화합물 등인데, starter culture로 사용될 유산균을 선발할 때에는 acetaldehyde, diacetyl, ehanol, propane, 2-butanone 등의 농도를 고려해서 결정한다. 특히, 발효유에서는 vicinal ketones 2,3-butanedione과 2,3-pentanedione이 주요한 향미성분으로 알려져 있으며, acetaldehyde는 향미성분 중 
에서 가장 많은 양을 차지하기 때문에 요구르트와 다른 발효유제품에서 요구르트의 독특한 향미를 주는 성분이다. 비록, 본 연구에서 향미성분 분석을 수행하지 않았지만 Kefir와 같은 발효 유제품의 starter 선정에는 이러한 향미성분의 특성을 고려하여 선발하는 것이 좋다.

\section{감사의 글}

본 연구는 산업통상자원부와 한국산업기술진흥원의 “R\&D재발견프로젝트”의 지원을 받아 수행된 연 구결과(과제번호: N0002488)로 이에 감사드립니다. 또한 Fig. 1의 그림을 사용할 수 있도록 허가해 준 Aniika Nilsson(Dairy Processing Handbook, Petra Pak)에게 감사드립니다.

\section{References}

Assadi, M. M., Pourahmad, R. and Moazami, N. 2000. Use of isolated kefir starter cultures in kefir production. World Journal of Microbiology and Biotechnology 16:541543.

Bylund, G. 2003. Dairy processing handbook. Tetra Pak Processing Systems AB.

Cogan, T. M., Barbosa, M., Beuvier, E., Bianchi-Salvadore, B., Cocconcelli, P. S., Fernandes, I., Gomez, J., Gomez, R., Kalantzopoulos, G., Ledda, A., Medina, M., Rea, M. C. and Rodriguez, E. 1997. Characterization of lactic acid bacteria in artisanal dairy products. Journal of Dairy Research 64:409-421.

Fujisawa, T., Adachi, S., Toba, T., Arihara, K. and Mitsuoko, T. 1988. Lactobacillus kefiranofaciens sp. nov. isolated from kefir grains. International Journal of Systematic Bacteriology 38:12-14.

Garrote, G. L., Abraham, A. G. and De Antoni, G. L. 1997. Preservation of kefir grains, a comparative study. Lebensmittel-Wissenschaft und Technologie 30:77-84.

Guzel-Seydim, Z., Seydim, A. C. and Greene, A. K. 2000. Organic acids and volatile flavor components evolved during refrigerated storage of kefir. Journal of Dairy Science 83:275-277.

Kakkar, P., Das, B. and Viswanathan, P. N. 1984. A modified spectrophotometric assay of superoxide dismutase. Indian J. Biochem Biophys. 21:130-132.

Kandler, O. and Kunath, P. 1983. Lactobacillus kefir sp. nov., a component of the microflora of kefir. Systematic and Applied Microbiology 4:286-294.

Kwak, H. S., Park, S. K. and Kim, D. S. 1996. Biostabilization of kefir with a nonlactosefermenting yeast. Journal of Dairy Science 79:937-942.

Maffei Facino, R., Carini, M., Aldini, G., Berti, F. and Rossoni, G. 1999. Panax ginseng administration in the rat prevents myocardial ischemia-reperfusion damage induced by hyperbaric oxygen: Evidence for an antioxidant intervention. Planta Med. 65:614619.

Micheli, L., Uccelletti, D., Palleschi, C. and Crescenzi, V. 1999. Isolation and characterization of a ropy Lactobacillus strain producing the exopolysaccharide kefiran. Applied Microbiology and Biotechnology 53:69-74.

Miller, J. H. 1972. Experiments in molecular genetics. Cold Spring Harbor Laboratory Press, NY, pp. 352-355.

Pintado, M. E., Lopes Da Silva, J. A., Fernandes, P. B., Malcata, F. X. and Hogg, T. A. 
1996. Microbiological and rheological studies on Portuguese Kefir grains. International Journal of Food Science and Technology 31:15-26.

Prado, M. R., Blandón, L. M., Vandenberghe, L. P. S., Rodrigues, C., Castro, G. R., Thomaz-Soccol, V. and Soccol, C. R. 2015. Milk kefir: Composition, microbial cultures, biological activities, and related products. Frontiers in Microbiology 6:1-10.

Takizawa, S., Kojima, S., Tamura, S., Fujinaga, S., Benno, Y. and Nakase, T. 1998. The composition of the Lactobacillus flora in kefir grains. Systematic and Applied Microbiology 21:121-127.

Tamime, A. Y. and Robinson, R. K. 1999. Yoghurt: Science and technology. Woodhead Publishing.

Witthuhn, R. C., Schoeman, T. and Britz, T. J. 2004. Isolation and characterisation of the microbial population of different South African Kefir grains. International Journal of Dairy Technology 57:33-37.

Wouters, J. T. M., Ayad, E. H. E., Hugenholtz, J. and Smit, G. 2002. Microbes from raw milk for fermented dairy products. International Dairy Journal 12:91-109.

Wyder, M., Keile, L. and Teuber, M. 1999. Description of Saccharomyces turicensis sp. nov., a new species from kefir. Systematic and Applied Microbiology 22:420-425. 